\title{
Tribunal de Justiça do Distrito Federal
}

\section{AGRAVO DE PETIÇÃO N. ${ }^{\circ} 8.277$}

A gratificação pro-labore facto apresenta serviço já prestado e a gratificiçãao pro labore faciendo também chamada gratifícação de função, é estatuida para serviços extraordinários ou não, que forem prestados.

Pode-se dizer que a lei nova regula inteiramente a matéria da lei anterior. quando, dispondo sôbre os mesmos fatos ou idênticos institutos juridicos, os abrange em sua complexidade.

Relator: Sr. Desembargador NeLSON RIBEIRO Alves.

Agravantes: Maria de Lourdes Cardoso e outros.

Agravada: Prefeitura do Distrito Federal.

\section{ACóRDÃ̀o DA $1^{*}$ CÂMARA CÍvEL}

Vistos, relatados e discutidos os presentes autos de Agravo de Petição n. ${ }^{\circ} 8.277$, sendo agravante MARIA DE LouRdes CARDOSO e outros e agravada a Prefeitura do Distrito Federal.

Acördam os Juizes da Primeira Câmara Civel do Tribunal de Justiça do Distrito $\mathrm{Fe}$ deral, por votação unânime, negar provimento ao recurso.

Os agravantes afirmaram, na inicial, que os Técnicos de Educação tinham direito a aumento de vencimentos, mediante o decurso

Com o advento da Lei n. ${ }^{\circ} 840$, de 1956 , dois decênios, evidenciando, assim, que ditos aumentos ficaram incorporados, definitivamente, aos vencimentos, os quais, em principio, estavam estabelecidios na letra «N» e passariam a ser, finalmente, da letra $\langle P\rangle$.

Com o advento da Lei n. ${ }^{\circ} 840$, de 1956 , o seu art. $4 .^{\circ}$ estabeleceu, expressamente, que ficavam «assegurados aos Técnicos de Educação as vantagens de que trata o art. $2 .^{\circ}$ da Lei n..$^{\circ} 761$, de 12 de dezembro de 1952», ou melhor, os «aumentos qüinqüienais corresponderiam a $20 \%$ (vinte por cento) sôbre os respectivos vencimentos», afirmando os agravantes em tal conjuntura, que os respectivos quinqüênios só podem ser computados na base do vencimento - letra $\langle\mathrm{P} \gg-\mathrm{e}$ não calculados sôbre o vencimento antigo e inicial - letra «N».

Temístocles Brandão Cavalcanti, fazenc.o um estudo a respeito de gratificações adicionais, teve oportunidade de assinalar que muitas vêzes a lei tem atribuido ao funcionário, em virtude de seu tempo de serviço, um adicional ou seu vencimento.

Isto importa em um acréscimo no seu estipêndio que se incorpora aos vencimentos, pelo menos durante a sua atividade.

Costuma-se, por isso, distinguir, como já vimos, a gratificação pro-labore facto, isto é, pelos serviços já prestados, pelo tempo de serviço, da gratificação pro-labore faciendo, isto é, pelos serviços extraordinários, ou não, que forem prestados; é também esta chamada gratificação de função.

Tratamos aqui, apenas, da primeira modalidade, que representa um verdadeiro aumento de ordenado, um estimulo, uma melhoria, em virtude dos serviços já prestados durante um longo periodo de atividade funcional.

Conquanto sujeita nossa história administrativa, a continuadas modificações, a gratificação adicional revestiu-se sempre dêsse caráter, integrando-se nos vencimentos do funcionário, incorporando-se a êles. Já o Conselho de Estado, em uma resolução de 19 de janeiro de 1834 , definindo a gratificação adicional declarava que, sendo devida por serviços já prestados, não se podieria exigir o efetivo exercício para seu pagamento: “A gratificação dessa espécie é pro-labore facto e não pro-labore faciendo é mais um aumento de ordenado, que gratificação pròpriamente; é como uma tença ou pensão com que a lei remunera o empregado, a cujo patrimônio se incorpora...".

Este o conceito geralmente fixado também pela jurisprudência administrativa e judicial ("Tratado de Direito Administrativo", vol. IV, p. 253, edição de 1956). 
Ressaltou, em consequiência, que o aumento de adicionais, previsto na Lei n. ${ }^{\circ} 532$, de 1950 , resultou de um pro-labore facto e não pelo pro-labore faciendo, sendo que o último caracterizaria, por exemplo, a gratificação de magistério, isto é, pelos serviços extraordinários ou não que tivessem a prestar também, chamada gratificação de função, o que teria levado os doutos da Municipalidade a uma discussão estéril, a fim de provar se tais expressões - aumento decenal e gratificação de magistério - eram ou não sinônimos.

Ficou evidenciado, na espécie, que o aumento de adicionais era imputado por um pro-labore facto, previsto em lei especifica (Lei n. ${ }^{\circ}$ 532, de 1950), mas a Municipalidade houve por bem de alterar dita modalidade para os Técnicos de Educação, estabelecendo, na Lei $n .^{\circ} 840$, de 1956, que aos mesmos eram aplicadas as vantagens dos aumentos qüinqüenais, ou melhor as modalidades de decênios (dois períodos) passariam a ser de qüinqüênios (cinco periodos), aproveitando aos Técnicos de Educação, dessarte, mais cinco anos de serviços pro-labore facto, pois a lei revogada previa, apenas, vinte anos, ao passo que a lei nova compreendeu o periodo de vinte e cinco anos.

Dá-se a revogação tácita ou indireta da lei, adverte o Desembargador Serpa Lopes, «quando, embora não expressamente estabelecida pela lei tal resulta de circunstâncias inequivocas, direta ou indiretamente por ela previstas. Segundo se observa do art. 2. da Lei de Introdução, dois são os elementos identificadores da revogação tácita: $10^{\circ}$ ) no caso de incompatibilidade não deve orientarse tão só pela consideração da vontade do legisladior senão igualmente pela observação bem atenta dessa incompatibilidade. Fôrça é ressaltar que a revogação tácita não se presume; para que ela se opere, é necessária a presença de uma incompatibilidade absoluta, formal. O segundo caso de revogação indireta opera-se quando a lei nova regula inteiramente a matéria contida na anterior. Assim, v.g., se um novo Código Comercial fôsse promulgado facto, revogada. Pode-se dizer que a lei nova regula inteiramente a matéria da lei anterior, quando, dispondo sô- bre os mesmos fatos ou idênticos institutos juridicos, os abrange em sua complexidade. Fora dêsse caso especial que a lei destacou, nos demais prevalece sempre o principio comum da revogação da lei anterior pela posterior, na proporção de sua incompatibilidade com a lei nova: posteriores leges ad prioris pertinent nisi contrariar sint. Não pode alcançar outras leis ou disposições estranhas. Contudo a revogação indireta de uma disposição da lei antiga implica a de tôdas as outras disposições existentes com os seus corolários ou desenvolvimentos» (Curso de Direito Civil, volume I, pp. 94 e 95).

Ora, os aumentos decenais ou qüinqüenais só podiam ser admitidos pelo pro-labore facto, pois, o primeiro, em verdade, também dependia do transcurso de tempo de serviço (artigo $4 .^{\circ}, \$ 1 .^{\circ}$, da Lei $n .^{\circ} 532$, de 1950), evidenciando, dessarte, que a lei nova passou a regular inteiramente a matéria da lei anterior, isto é, os aumentos por tempo de serviço prestados, pois, do contrário, seria admitir a aplicação de um verdadeiro bis in idem, ou melhor, os aumentos decenais e os quinqüenais pelo mesmo tempo de serviço já prestados, o que acarretaria uma interpretação inaceitável.

Carlos Maximiliano prontificou que "se a lei nova cria, sôbre o mesmo assunto, da anterior, um sistema inteiro completo, diferente, é claro que todo o outro sistema foi eliminado. Por outras palavras: dá-se ab-rogação, quando a norma posterior cobre com o conteúdo todo da antiga" (Hermenêutica e Aplicação do Direito", edição de 1925, página 367).

$\mathrm{O}_{\mathrm{S}}$ qüinqüênios, portanto, só podiam ser computados sôbre o vencimento base inicial - letra «N», de cargo isolado, e não como pleitearam os agravantes, isto é, a incidência dos mesmos sôbre a letra $« \mathrm{P} »$.

Rio, 20 de maio de 1957. - José Murta RibeIRo, Presidente interino. - NELSON RIBeIro Alves, Relator. - Paulo Alonso.

Registrado em 29 de julho de 1957.

Publicado no Diário da Justiça de 19-6-58 - apenso ao n. ${ }^{\circ} 137$, p. 1.902 . 